\title{
POTRET KEKUATAN MULTIKULTURALISME DALAM INSTITUSI POLITIK
}

\author{
Fathullah Syahrul \\ Departemen IImu Politik, FISIP, Universitas Padjadjaran \\ Fathullah18001@mail.unpad.ac.id \\ Bandung - Indonesia
}

\begin{abstract}
The study of the relations of cultural elements, namely multiculturalism and politics, is still relatively developed. Because, the study is vulnerable to conflict, especially when faced with the word majority and minority in the realm of political institutions. As a country with a pluralistic background inhabited by various ethnicities, racial religions and Indonesian culture, certainly requires an in-depth study of the fulfillment of minority rights in political instiusi. This paper is a simple theoretical study of a combination of multiculturalism and institutionalism approaches to explain the prospects of minority involvement in formulating public policies and political institutions that must be present in accommodating the political rights of minority groups. The conclusions in this article are, the power of multiculturalism in political institutions is as follows: (1) multicultural countries must be able to provide lessons for the whole world about the meaning of diversity; (2) the institution becomes a bridge in absorbing all the aspirations of the people and carrying out the law and applying the law indiscriminately; (3) multiculturalism is actually not enough to discuss minority rights in political institutions but conflicts with grassroots sources; (4) the strength of multiculturalism in political institutions is how this study works in maintaining the harmony of the nation and state.
\end{abstract}

\section{Keywords: Multiculturalism; Political Institutions}

\begin{abstract}
Abstrak
Kajian tentang relasi unsur-unsur kebudayaan yakni multikulturalisme dengan politik masih relatif berkembang. Sebab, kajian tersebut rentan dengan konflik apalagi ketika diperhadapkan dengan kata mayoritas dan minoritas pada ranah institusi politik. Sebagai negara dengan latar belakang kemajemukan yang dihuni oleh bermacam-macam suku, agama ras dan budaya Indonesia tentu membutuhkan sebuah kajian mendalam tentang pemenuhan hak-hak minoritas dalam instiusi politik. Tulisan ini merupakan telaah teoritik sederhana mengenai kombinasi pendekatan multikulturalisme dan institusionalisme untuk menjelaskan prospek keterlibatan kelompok minoritas dalam merumuskan kebijakan publik dan juga institusi politik yang harus hadir dalam mengakomodasi hak-hak politik kelompok minoritas. Simpulan dalam artikel ini adalah, kekuatan multikulturalisme dalam institusi politik sebagai berikut: (1) negara multikultural harus mampu memberikan pelajaran bagi seluruh dunia tentang arti keberagaman; (2) institusi menjadi jembatan dalam menyerap segala aspirasi masyarakat dan menjalankan hukum serta menerapkan hukum tanpa pandang bulu; (3) multikultural sebenarnya tidak cukup membahas tentang hak-hak minoritas dalam institusi politik tetapi konflik-konflik yang sumbernya dari akar rumput; (4) kekuatan dari multikulturalisme dalam institusi politik adalah bagaimana kajian ini bekerja dalam menjaga keharmonisan bangsa dan negara.
\end{abstract}

\section{Kata Kunci: Institusi Politik; Multikulturalisme}

Open Access at: http://ojs.uho.ac.id/index.php/PUBLICUHO/index

Journal Publicuho is licensed under a Creative Commons Attribution 4.0 International License. 


\section{PENDAHULUAN}

Sebagai negara yang berlatar belakang suku, agama ras dan budaya yang majemuk Indonesia membutuhkan sebuah instrumen dan kajian strategik dalam rangka menciptakan persatuan dan kesatuan. Hal ini sebenarnya telah termaktub dalam sila ketiga Pancasila, Persatuan Indonesia. Menjaga keutuhan bangsa agar terciptanya bangsa yang berdaulat adil dan makmur. Salah satu instrumen pendekatannya adalah multikultul.

Menurut Taria Modood (dalam Hoon: 2013) adalah suatu istilah yang menarik. la bisa dipahami berbeda oleh banyak negara tergantung latar belakang sosial politik yang mengiringi kemunculan istilah ini. Seperti halnya dengan negara Amerika Serikat, multikulturalisme diartikan secara politik digunakan untuk mengakui hak asasi manusia dan kesetaraan warga negara sebagai respon atas meningkatnya klaim perbedaan kelompok, seperti etnis Afrika, kelompok etnis minoritas, perempuan, gay dan lain sebagainya.

Berbeda dengan negara-negara Eropa, multikulturalisme adalah respon yang muncul dari imigrasi pendatang dari luar Eropa, dari orang non-kulit putih yang masuk ke negara-negara mayoritas kulit putih. Dalam hal ini, multikulturalisme berbentuk pengakuan atas kelompok-kelompok yang berbeda pada konsekuensi imigrasi dan perjuangan dari beberapa kelompok marjinal.

Para ilmuwan sosial biasanya mempergunakan konsep masyarakat (society) untuk mengidentifikasi orang sesuai dengan hubungan mereka satu sama lain dan keindependenan mereka dari yang lain, sedangkan konsep budaya (culture) untuk mengidentifikasi orang sesuai dengan apa yang mereka yakini, apa mereka lakukan, apa yang mereka ketahui, dan bagaimana mereka berindak. Ringkasnya, seluruh yang dipelajari manusia adalah kultur (Lubis, 2019).

Setiap manusia pasti mempelajari kultus masyarakatnya. Di antara unsur budaya yang paling signifikan yang harus dipelajari seseoang adalah nilai (valve), norma (norms) dan peranan (roles). Nilai-nilau sebuah kultur mengindetifikasi yang dianggap ideal, tujuan paling tinggi dan standar paling umum untuk memastikan baik dan buruk atau atau yang disukai dan dibenci.

Seperangkat gagasan diatas menjadi sebuah proses dialektis terhadap bangsabangsa yang hidup di negara berkembang seperti Indonesia. Dengan berbagai macam suku agama, ras dan budaya. Sebab, isu-isu etnis rentang akan hadirnya konflik antar sesama anak bangsa. Lembaga IImu Pendidikan Indonesia (LIPI) merilis penelitian Selasa, 7 Agustus 2018 tentang proses kapitalisasi dan manipulasi isu-isu SARA.

Dalam penelitian tersebut diungkapakan bahwa tindakan persekusi yang belakangan merak terjadi di masyarakat mayoritas disebabkan penyebaran berita hoaks (92,4 persen), ujaran kebencian (90,4 persen), radikalisme (84,2 persen), kesenjangan sosial (75,2 persen), perasaan terancam oleh orang atau kelompok lain (71,1 persen), sedangkan 
aspek "relijiutas" (67,6 persen) dan ketidakpercayaan antar kelompok/suku/agama/ras (67,6 persen). Fenomena ini tentu menjadi sesuatu yang menakutkan, mengingat Indonesia adalah salah satu negara yang heterogen tentu instrumen tentang multikultural tetap akan subur. Salah satu poin dari instrumenn tersebut adalah agama, agama Islam sebagai agama mayoritas, pertanyaan yang sering muncul dari kalangan ilmuwan adalah mengapa Islam menjadi agama mayoritas di Indonesia? Jika diasumsikan dalam aspek sejarah, proses penyebaran agama Islam di Nusantara (sekarang Indonesia).

Islam dibawa ke Nusantara oleh pedagang dari Gujarat, India selama abad ke-11, meskipun Muslim telah mendatangi Nusantara sebelumnya. Pada akhir abad ke-16, Islam telah melampaui jumlah penganut Hindu dan Buddhisme sebagai agama dominan bangsa Jawa dan Sumatra. Bali mempertahankan mayoritas Hindu, sedangkan pulau-pulau timur sebagian besar tetap menganut animisme sampai abad 17 dan 18 ketika agama Kristen menjadi dominan di daerah tersebut.

Penyebaran Islam di Nusantara pada awalnya didorong oleh meningkatnya jaringan perdagangan di luar kepulauan Nusantara. Pedagang dan bangsawan dari kerajaan besar Nusantara biasanya adalah yang pertama mengadopsi Islam. Kerajaan yang dominan, termasuk Kesultanan Mataram (di Jawa Tengah sekarang), dan Kesultanan Ternate dan Tidore di Kepulauan Maluku di timur. Pada akhir abad ke-13, Islam telah berdiri di Sumatera Utara, abad ke-14 di timur laut Malaya, Brunei, Filipina selatan, di antara beberapa abdi kerajaan di Jawa Timur, abad ke-15 di Malaka dan wilayah lain dari Semenanjung Malaya (sekarang Malaysia). Meskipun diketahui bahwa penyebaran Islam dimulai di sisi barat Nusantara, kepingan-kepingan bukti yang ditemukan tidak menunjukkan gelombang konversi bertahap di sekitar setiap daerah Nusantara, melainkan bahwa proses konversi ini rumit dan lambat (M.C. Ricklefs, 1991).

Hal di atas menunjukkan proses penyebaran serta hadirnya Islam di Indonesia memang memiliki rentan waktu yang cukup panjang bahkan berabad-abad lamanya. Dari rentetan sejarah itulah beragam tokoh-tokoh penyebar Islam di Indonesiapun bermunculan. Sebut saja, Abdurrauf Singkel dan Muhammad Yusuf Al-Makassari pada abad ke-17. Wajah Islam yang dikenalkan oleh dua ulama ini bercorak puritan dan menganggap bahwa itu bentuk keberagamaan Islam yang paling benar dan ideal. Diaras ini, tradisi lokal masyarakat yang relevan dengan nilai-nilai Islam dintegrasikan menjadi sebuah tradisi beragama (Islam). Adat, tradisi, dan budaya lokal dinilai bukan sebagai ancaman terhadap otentisitas Islam.

Kajian tentang sejarah masuknya Islam di Indonesia tentu menjadi sesuatu yang sangat penting, mengingat agama Islam menjadi agama yang mayoritas di Indonesia yang mesti menjadi sentral dalam mengakomodasi hak-hak minoritas di segala aspek kehidupan. Kajian tentang masyarakat mayoritas harus mengakomodasi hak-hak minoritas adalah 
sebuah tantangan tersendiri. Mengapa demikian, Pertama, pengakuan dan penghormatan terhadap hak-hak minoritas oleh kelompok mayoritas bukan perkara mudah. Sebagai kelompok mayoritas, umat muslim Indonesia kurang merasakan menjadi kelompok minoritas. Kecuali di beberapa wilayah di mana umat Islam sebagai minoritas seperti di Bali, NTT, atau wilayah Papua, secara umum umat Islam Indonesia tidak memiliki beban psikologis seperti yang dirasakan minoritas. Apalagi jika dibandingkan dengan keberadaan umat muslim di negara-negara yang mayoritas berpenduduk non-muslim. Apa yang dirasakan umat Islam Indonesia tentu tidak sama dengan yang dirasakan umat muslim di negara-negara Eropa, Australia dan Amerika. Problem relasi mayoritas-minoritas sebetulnya adalah problem khas minoritas. Maka jika umat Islam yang mayoritas harus berbicara tentang hak-hak minoritas tentu hal ini menjadi sesuatu yang menantang (challenging) (Suprapto, 2012).

Kedua, sebagai umat mayoritas di Indonesia, umat Islam secara tidak langsung memiliki tanggungjawab moral untuk mengembangkan sebuah pola hubungan dengan minoritas secara ramah, produktif dan humanis. Apalagi jika dikaitkan dengan munculnya berbagai konflik kekerasan bernuansa agama dalam dua dekade terakhir yang terjadi di sejumlah daerah dengan korban yang tak sedikit, maka umat Islam lah yang juga paling banyak menanggung akibatnya.

Ketiga, munculnya serangkaian radikalisme dan tindak kekerasan yang mengatasnamakan agama, kerap menjadikan Islam sebagai tertuduh. Hal ini jelas merusak citra posisitif Islam sebagai agama yang cinta damai.

Keempat, pola hubungan damai yang dikembangkan oleh Islam di Indonesia pada gilirannya akan berkontribusi bagi kelangsungan Negara Kesatuan Republik Indonesia (NKRI) sekaligus dapat disumbangkan bagi penciptaan peradaban dunia yang lebih damai. Di saat sebagian negara-negara Barat menaruh curiga dan pada tingkat tertentu phobia terhadap Islam atau negara-negara Timur Tengah, sebetulnya Barat menaruh harapan akan hadirnya wajah Islam yang damai dari Indonesia. Wajah Islam Indonesia diakui sebagai Islam moderat yang lebih toleran terhadap perbedaan.

Islam sebagai masyarakat mayoritas memiliki tanggungjawab dalam mengakomodasi hakhak minoritas dalam institusi politik. Sebab, institusi politik sebagai wadah dalam mengimplementasikan dialog antar umat beragama. Institusi politik sebagai jembatan bagi seluruh anak bangsa dalam rangka merumuskan kebijakan publik sehingga terciptanya proses pembangunan demokrasi yang produktif.

Hal tersebut juga diatur dalam Undang-undang perlindungan hukum terhadap hak asasi kelompok-kelompok minoritas di Indonesia dalam pasal 28 D dan pasal 28 I Undang-undang Dasar 1945, serta tercantum juga di Pasal 3 ayat (3) Undang-undang nomor 39 Tahun 1999 tentang Hak Asasi Manusia (HAM), sedangkan pasal 27 Kovenan Internasional Hak-Hak Sipil dan Politik (Internasional Covenant and Political Right) yang telah diratifikasi dengan 
Undang-undang Nomor 12 tahun 2005 mengatur bahwa kelompok minoritas harus diakui berbagai haknya. Salah satu permasalaham dalam penyelenggaraan hak-hak minoritas di Indonesia adalah lemahnya penegakan hukum dan pembangunan yang berkeadilan serta perlakuan diskriminatif lainnya masih terjadi kepada mereka. Sudah sepatunya pemerintah mengedepankan pendekatan berbasis Hak Asasi Manusia (HAM) (Right Based Approach) dalam seluruh proses pembangunan program dan kebijakan yang disusun sesuai dengan upaya perlindungan serta pemenuhan hak-hak kelompok minoritas (Danang Risdiarto, n.d.).

Sedangkan Komnas HAM memberikan defenisi minoritas dengan kata-kata kunci yang harus dipertimbangkan yaitu: "secara leksikal, istilah "minoritas" dapat dipahami secara numerik yaitu sebagai populasi yang jumlahnya sebagai populasi yang jumlahnya lebih sedikit dari sebuah jumlah populasi yang lebih besar secara keseluruhan (di tingkat nasional). Tapi minoritas juga dapat dilihat dalam hal pengaruh, yaitu tidak dominan, dan mendapatkan perlakuan yang merugikan atau berada dalam situasi yang tidak dominan, dan mendapat perlakuan atau berada dalam situasi yang tidak diuntungkan dalam kehidupan bermasyarakat dan bernegara.

Kata minoritas sebenarnya dapat menjadi penyulut konflik di masyarakat. Sebab, kata ini menjadi satu diskursus yang agak sensitif jika diperhadapkan ke ranah sosial. Seperti yang diungkapkan Imanuel Subangun dalam bukunya Negara Anarkhi. Subangun mengatakan, bahwa sebenarnya kita ini sedang dikotak-kotakkan dengan improvisasi kata-kata termasuk Orde Lama, Orde Baru dan Reformasi. Kata minoritas menjadi satu tantangan bagi negaranegara multikultural termasuk Indonesia.

Sebagai negara yang menganut sistem demokrasi, multikultaralisme adalah salah satu pendekatan yang paling efektif dalam melihat realitas sosial di masyarakat. Begitu juga Indonesia dikenal sebagai negara hukum serta dalam sebuah institusi baik formal maupun non-formal institusi dianggap sebagai jembatan bagi para pemangku kebijakan untuk menjalan tugas dan fungsi negara. Salah satunya adalah mengakomodir seluruh kepentingan masyarakat baik itu kelompok minoritas maupun mayoritas sesuai dengan undang-undang yang dijelaskan diatas.

\section{TINJAUAN LITERATUR}

\section{Konsep Multikulturalisme}

Multikulturalisme adalah sebuah filosofi terkadang juga ditafsirkan sebagai ideologi, namun yang pasti itu adalah sebuah konsep tentang upaya yang menghendaki adanya persatuan dan berbagai kelompok kebudayaan yang saling berbeda dengan hak dan status sosial politik yang sama dalam masyarakat modern. Istilah multikulturalisme juga sering digunakan untuk menggambarkan kesatuan berbagai etnis masyarakat yang berbeda dalam suatu negara. Multikulturalisme bertentangan dengan monokulturalisme dan asimilasi yang telah 
menjadi norma dalam paradigma negara bangsa (nation-state) sejak awal abad ke 19 (Bissondath, 2002).

Monokulturalisme menghendaki adanya kesatuan budaya secara nomatif, sementara asimilasi adalah timbulnya keinginan untuk bersatu antara dua atau lebih kebudayaan yang berbeda dengan cara mengurangi perbedaan-perbedaan sehingga tercipta sebuah kebudayaan baru. Jadi multikulturalisme adalah suatu filosofi yang mengarahkan semua pihak agar mau saling mendengar dan memahami satu sama lain, tanpa harus menanggalkan prinsip dan keyakinan pribadinya. Dengan penegakan filosofi multikulturalisme ini maka diharapkan warga suatu negara yang heterogen bisa hidup bersamasama meskipun berbeda etnis, agama dan ras, sehingga mereka akan dapat saling menghormati dan muncul sikap toleransi (Bond, 2006).

Secara konsep, multikulturalisme dalam politik menghendaki sebuah bentuk kesetaraan, salah satu jalan untuk memenuhi kehendak tersebut melalui institusi politik. sebab, dalam sebuah institusi politik akan memunculkan kebijakan-kebijakan dalam rangka memenuhi hak-hak warga tanpa memandang latar belakang suku, ras, agama dan budaya. Sehingga tak ada lagi fenomena tumpang tindih yang berujung pada konflik.

Politik multikulturalisme mengakomodasi sekaligus dua hal yang selama ini dipertentangkan yaitu kesetaraan dan perbedaan. Gagasan ini dianggap mampu meredam konflik vertikal dan horisontal yang terjadi dalam masyarakat di negara-negara dengan tingkat heterogenitas tinggi, akibat adanya tuntutan pengakuan atas keberadaan dan keunikan budaya kelompok etnis dalam masyarakat tersebut. Dengan demikian memberikan keleluasaan bagi berbagai identitas kelompok untuk melaksanakan kehidupannya secara lebih otonom (Nugroho, 2013).

Memahami multikulturalisme membutuhkan pemahaman yang lebih arif bagi konsep-konsep di dalamnya. Pertama, konsep keragaman dalam masyarakat multikultural tidak hanya berlaku untuk identitas etnis atau kesukuan, melainkan juga bagi identitas lainnya seperti ras, kelas, gender dan agama. Masing-masing kelompok dalam masyarakat berhak mengidentifikasi dirinya dengan perangkatperangkat yang membentuk identitas tersebut, apakah bahasa, sikap, nilai praktek politik dan sebagainya. Kedua, sebagai implikasi pemahaman di atas maka kultur-kultur kemudian tidak lagi dipahami sebagai produk jadi atau hasil aktivitas manusia. Kultur harus dipahami sebagai bentuk proses kontinum aktivitas dan dinamika anggota kelompoknya. Dalam masyarakat multikultural, nilai kultural ini akan saling berinteraksi dan melengkapi satu sama lain dengan mendasarkan diri pada kesetaraan dan toleransi (Parekh, 2001).

Istilah multikulturalisme mengandung tiga komponen, yakni terkait dengan kebudayaan, konsep ini menunjuk kepada pluralitas kebudayaan dan cara tertentu untuk merespon pluralitas itu. Oleh karena itu, multikulturalisme bukanlah doktrin politik pragmatik 
melainkan sebagai cara pandang kehidupan manusia. Karena hampir semua negara di dunia tersusun dari aneka ragam kebudayaan, artinya perbedaan menjadi asasnya, dan gerakan manusia dari satu tempat ke tempat lain di muka bumi semakin intensif maka multikulturalisme itu harus diterjemahkan kedalam kebijakan multikultural yaitu sebagai politik pengelolaan perbedaan kebudayaan warga negara (Nugroho, 2013).

Ada tiga model kebijakan multikultural negara untuk menghadapi keanekaragaman etnis, suku, kelas, gender, agama dan lain- lain. Pertama, model yang mengedepankan nasionalitas. Nasionalitas adalah sosok baru yang dibangun bersama tanpa memperhatikan aneka ragam suku, bangsa, agama dan bahasa, dan nasionalisme bekerja sebagai perekat integrasi. Dalam kebijakan ini setiap orang, bukan kolektif, berhak untuk dilindungi negara sebagai warga negara. Model ini dipandang sebagai penghancur akar kebudayaan etnik yang menjadi dasar pembentukan negara dan menjadikannya sebagaimasa lampau saja. Model kebijakan multikultural ini dikhawatirkan terjerumus ke dalam kekuasaan otoritarian karena kekuasaan untuk menentukan unsur-unsur integrasi nasional berada ditangan suatu kelompok elite tertentu. Kedua, model nasionalitas etnik, yang mendasarkan kesadaran kolektif etnik yang kuat yang landasannya adalah hubungan darah dan kekerabatan dengan para pendiri nasional (founders). Selain itu kesatuan bahasa juga merupakan ciri nasional etnik ini. Model ini dianggap sebagai model tertutup karena orang luar yang tidak memiliki sangkut paut hubungan darah dengan etnis pendiri nasional akan tersingkir dan diperlakukan sebagi orang asing. Ketiga, model multikultural etnik yang mengakui eksistensi dan hak-hak warga etnik secara kolektif. Dalam model ini keaneka ragaman menjadi realita yang harus diakui dan diakomodasi negara dan identitas serta asal usul warga negara diperhatikan.Isu-isu yang muncul karena penerapan kebijakan ini tidak hanya keanekaragaman kolektif dan etnik, tetapi juga isu mayoritas/minoritas, dominan tidak dominan. Persoalannya menjadi lebih kompleks lagi karena ternyata mayoritas tidak selalu berati dominan, karena berbagai kasus menunjukan bahwa minoritas justru dominan dalam ekonomi. Jika kekuasaan negara lemah karena prioritas kekuasaan dilimpahkan kepada keanekaragaman kolektif, sebagai konsekuensi pengakuan negara maka negara mungkin akan diramaikan konflik internal berkepanjangan yang pada gilirannya akan melemahkan negara itu sendiri (Poster, 1992).

Merujuk pada pernyatan diatas, pada abad ke-21 sekarang ini instusi politik belum sepenuhnya memfokuskan pada kebijakan-kebijakan dalam mengakomodasi hak-hak minoritas. Negara kita masih dikotak-kotakkan dengan isu-isu mayoritas dan minoritas, dapa kita saksikan pada masa reformasi sampai hari ini konflik mengenai suku, agama ras dan budaya masih menemui jalan buntu. Pernyataan Hungtington mengenai White Anglo Saxon Protestan vs Islam Confusian benar adanya. Islam sebagai agama mayoritas belum 
sepenuhnya mampu bernegosiasi dengan kelompok-kelompok minoritas, hal ini dapat dilihat dari konflik-konflik yang sampai hari ini masih memecah telinga kita. Seperti kasus di PosoAmbon, Kalimantan antara suku bugis vs suku dayak menjadi satu kesatuan yang harus diselesaikan oleh institusi politik.

Kebijakan-kebijakan yang dilahirkan tidak hanya basi di ruang-ruang rapat, akan tetapi implementasi dari kebijakan-kebijakan tersebut harus bisa dirasakan oleh seluruh masyarakat Indonesia. Konflik klasik yang berkepanjangan ini mestinya harus disudahi sebab, dalam rangka menjaga persatuan dan kesatuan bangsa diperlukan sebuah kebijakan penemuhan hak-hak politik serta hak menjalankan seluruh aktivitas warga.

\section{METODOLOGI}

Tulsian ini menggunakan pendekatan kualitatif dengan data dan informasi diperoleh melalui studi kepustakaan dan pengamatan fenomenologis terhadap kombinasi pendekatan multikulturalisme dan institusionalisme dalam sebuah institusi politik. Data-data serta argumentasi yang dibangun dalam tulisan ini menggunakan studi kualitatif, yakni dengan mengumpulkan berbagai referensi ilmiah dan dari sumber primer dan sekunder melalui penelusuran tulisan terkait buku, jurnal, paper, dan berita massa tentang peranan hak-hak mayoritas mengakomodasi hak minoritas dan institusi politik.

\section{HASIL DAN PEMBAHASAN}

\section{Kombinasi Multikulturalisme dan Institusionalisme}

Para ilmuwan sosial biasanya mempergunakan konsep masyarakat (society) untuk mengidentifikasi orang sesuai dengan hubungan mereka satu sama lain dan keindependenan mereka dari yang lain, sedangkan konsep budaya (culture) untuk mengidentifikasi orang sesuai dengan apa yang yang mereka lakukan, apa yang mereka ketahui, dan bagaiman mereka bertindak. Ringkasnya, seluruh yang dipelajari manusia adalah kultur. Dapat dikatakan bahwa, apa yang dilakukan manusia dalam kehidupan sehari-hari itu erat kaitannya dengan kultur. Penerimaan hak-hak minoritas dalam sebuah institusi diyakini sebagai sebuah kultur. Jadi seyogya masalah tersebut telah final, karena hukum juga telah mengungkap hal tersebut bahwa Indonesia dengan sistem demokrasi dan menjunjung tinggi asas tertinggi yaitu hukum harus mengakomodasi seluruh kepentingankepentingan dan hak-hak minoritas dan itu juga telah diperkuat oleh semboyan Bhineka Tunggal lka.

Namun ironisnya, gaya politik orde baru telah memberikan gambaran besar bagi kita bahwa penghilangan hak kelompok-kelompok minoritas nyata terjadi. Bagi mereka yang tidak ikut dengan budaya politik Soeharto maka haknya semakin terdegradasi bahkan tak dianggap kala itu. Orde baru tentu saja bukan suatu fenomena yang statis, tetapi secara 
bertahap berkembang a relatively hegemonic regime. Begitu juga hari ini, tantangan sebuah institusi akan duji sejauh mana ia akan merangkul hak-hak minoritas.

Pendekatan Legal/Institusional, yang sering dinamakan pendekatan tradisional, mulai berkembang abad 19 pada masa sebelum Perang Dunia II. Dalam pendekatan ini Negara menjadi fokus pokok, terutama dari segi konstitusional dan yuridisnya. Bahasan tradisonal menyangkut antara lain sifat dari undang-undang dasar, masalah kedaulatan, kedudukan dan kekuasaan formal serta yuridis dari lembaga-lembaga kenegaraan seperti parlemen, badan eksekutif dan badan yudikatif. Dengan demikian pendekatan tradisonal ini mencakup baik unsure legal maupun unsure institusional.

Seandainya kita ingin mempelajari parlemen dengan pendekatan ini maka yang akan dibahas adalah kekuasaan serta wewenang yang dimilikinya seperti tertuang dalam naskah-naskah resmi (undang-undang dasar, undang-undang atau peraturan tata tertib); hubungan formal dengan badan eksekutif; struktur organisasi (pembagian dalam komisi, jenjang-jenjang pembicaraan atau hasil kerjanya (berapa undang-undang telah dihasilkan) (Budiardjo, 2008).

Para peneliti tradisional tidak mengkaji apakah memang lembaga itu terbentuk dan berfungsi seperti yang dirumuskan dalam naskah-naskah resmi tersebut, apalagi bertanya mengapa ada diskrepansi antara struktur formal dan gejala-gejala yang dapat diamati dalam praktik. Pada saat yang bersamaan pendekatan tradisonal tidak menghiraukan organisasi-organisasi informal, seperti kelompok kepentingan dan kelompok lainnya, dan juga media komunikasi. Bahasan ini lebih bersifat statis dan deskriptif daripada analitis, dan banyak memakai ulasan sejarah. Lagi pula dalam proses pembahasan, "fakta" (sesuatu yang dapat dibuktikan melalui pengalaman atau pengamatan) kurang dibedakan dengan norma (ideal atau standar yang harus menjadi pedoman untuk perilaku).Pendekatan tradisional lebih sering bersifat normatif (yaitu sesuai dengan ideal atau standar tertentu) dengan mengansumsikan norma-norma demokrasi Barat. Menurut penglihatan ini, Negara ditafsirkan sebagai suatu badan dari norma-norma konstitusional yang formal (a body of formal constitusional norms) (Easton, 1968).

Di samping itu, bahasan biasanya terbatas pada Negara-negara demokrasi Barat, seperti Inggris, Amerika, Prancis, Belanda dan Jerman. Dengan demikian dapat dipahami bahwa pendektan ini kurang member peluang bagi terbentuknya teori-teori baru.

Kajian teoritik tentang proses dialog antara multikulturalisme dan institusionalisme merupakan kajian yang relevan untuk melihat proses masyarakat multikultural dalam sebuah institusi politik. Sebab, sebuah institusi politik mesti yang melibatkan kelompok-kelompok minoritas dalam pengambilan keputusan. Institusi politik mengakomodasi hak-hak minoritas saat hak tersebut diambil melalui kekuasaan sehingga menghasilkan sebuah kebijakan yang 
mampu melahirkan kebijakan untuk seluruh masyarakat tanpa melihat latar belakang tertentu. Selain itu, harapan tersebut dapat diterapkan melalui jalur aturan dan Undangundang.

Pendekatan metodologi ilmu politik: institusionalisme/tradisional dan behavioralisme menjadi satu kesatuan yang dianggap produktif dalam melihat pola dan tingkah laku kelompok-kelompok minoritas dalam sebuah institusi politik. Sebab, dalam pendekatan pendekatan konstitusional adalah kekuasaan (asal-usul, pemegang, dan cara penyelenggaraannya) dalam konstitusi, dan segi yuridisnya konstitusi menatapkan kerangka filosofis dan organisasi, membagi tanggung jawab para penyelenggara negara, membuat, dan melaksanakan kebijaksanaan umum. Objek konstitusi adalah menyediakan undangundang dasar bagi setiap rezim pemerintahan. Dalam konstitusi dikemukakan bentuk negara yaitu federal dan kesatuan jenis sistem pemerintahan, yaitu parlementer atau presidensil. negara federal adalah yang otoritas dan kekuasaan terletak pada pemerintah. Pusatnya dibagi dalam beberapa negara bagian. negara kesatuan adalah negara otoritas dan kekuasaan pemerintah pusatnya disentralisasikan.

Maka timbul keinginan untuk merenungkan kembali pandangan ini, dan kembali memandang negara, dengan berbagai institusinya, sebagai instansi utama, yang merupakan faktor penting dalam menentukan dan membatasi berbagai aspek yang diutamakan oleh pendekatan behavioralis. Pendekatan institusionalisme baru menjelaskan bagaimana organisasi institusi itu, apa tanggung jawab dari setiap peran dan bagaimana peran dan institusi berinteraksi.

Muncul semacam konsensus bahwa inti dari institusi politik adalah rules of the game (aturan main). Yang menjadi masalah ialah aturan yang mana, dan bagaimana sifatnya, formal seperti perudang-undangan, atau informal seperti kebiasaan, norma sosial atau kebudayaan. Institusi tidak hanya merupakan refleksi dari kekuatan sosial. Intitusi seperti pemerintah, parlemen, partai politik, dan birokrasi mempunyai kekuatan sendiri, dan para aktor harus menyesuaikan diri padanya.

Dua pendekatan ini memang harus seiring sejalan, sebab pendekatan ini menyentuh harus sesuai dan berjalan serta berlaku untuk masyarakat multikultural dalam menjalankan tata kelola pemerintahan di Indonesia. Titik temu antara kajian teoritik dalam tulisan ini adalah terpenuhnya keseimbangan dalam merumuskan kebijakan dalam institusi politik sehingga terciptanya semua kebijakan yang dirasakan oleh seluruh masyarakat sebagai bagian dari cara kerja beberapa kajian teoritik yang digunakan sebagai instrumen dalam sistem tata kelola pemerintahan yang baik. Keseimbangan perilaku dari aktor-aktor politik dalam institusi politik akan menciptakan sebuah produk kebijakan yang nantinya juga akan seimbang dirasakan oleh seluruh masyarakat. 
Badan pembuat undang-undang (legislatif) berfungsi mengawasi penyelenggaraan negara oleh eksekutif. Anggota bada ini berasal dari anggota partai yang dipilih rakyat melalui pemilihan umum. Badan eksekutif sistem pemerintahan parlementer dikepalai perdana menteri, sementara pada sistem presidensil dikepalai oleh presiden. Para menteri pada sistem parlementer dipilih perdana menteri dari keanggotaan legislatif. Dalam sistem presidensil, para menteri dipilih secara prerogatif oleh presiden. Badan yudikatif melakukan pengawasan atas kinerja seluruh lembaga negara (legislatif maupun eksekutif). Lembaga ini melakukan penafsiran atas konstitusi jika terjadi persengketaan antara legislatif dan eksekutif. Lembaga asal-muasal pemerintahan adalah partai politik. Partai politik menghubungkan antara kepentingan masyarakat umum dan pemerintah melalui pemilihan umum. Di samping partai politik, terdapat kelompok kepentingan, yaitu kelompok yang mampu mempengaruhi keputusan politik tanpa ikut ambil bagian dalam sistem pemerintahan. Ada juga kelompok penekan, yaitu kelompok yang secara khusus dibentuk untuk mempengaruhi pembuatan kebijaksanaan umum di tingkat parlemen. Dalam menjalankan fungsinya, eksekutif ditopang oleh (administrasi negara), yang terdiri atas birokrasi-birokrasi sipil, yang berfungsi melakukan pelayanan publik (Mufti, 2012)

Kajian teoritik ini diprioritaskan bagi partai politik sebagai lembaga yang menjembatani kelompok-kelompok minoritas terlibat dalam institusi politik. Semua proses tersebut dilakukan oleh para aktor-aktor politik dalam rangka meweujudkan kebijakan kebijakan yang merata sebagai bagian dari cara kerja mesin partai politik.

\section{Pentingnya Mengakomodasi Hak Minoritas}

Demokrasi itu merupakan bentuk pemerintahan yang paling buruk, tetapi masalahnya, bentuk lainnya tidak lebih baik daripada demokrasi" (Winston Churcill: 1947). Penggalan kalimat yang ditulis Winston ini menjadi perdebatan dalam menatap masa depan demokrasi khususnya di Negara-negara berkembang. Perbincangan demokrasi sebenarnya memang harus diakui menjadi satu dimensi kekuatan dalam sistem tata kelola Negara, dimana demokrasi bekerja.

Salah satu wacana perbincangan publik akademis saat kemenangan demokrasiliberal atas komunisme yang ditandai dengan bubarnya Uni Soviet, "The End of History" kata Francis Fukuyama 1989. Fukuyama mengingatkan kepada kita tentang kesuksesan demokrasi di Negara-negara maju dan berujung tragis pada negara-negara berkembang. Tetapi, bukan berarti suara-suara minor tentang demokrasi tak nyaring bunyinya. Tesis yang dikatakan Fukuyama itu sah-sah saja, mengingat dalam proses menatap demokrasi di masa depan. Realisme demokrasi di Negara berkembang mengalami tantangan yang luar biasa hingga hari ini. Fenomena kesuksesan demokrasi di negara maju berubah menjadi momok yang menakutkan di negara berkembang. 
Jika melihat realitas demokrasi di negara berkembang, kelompok-kelompok minor sebelumnya telah mengingatkan kita bahwa demokrasi akan berjalan dalam realitas politik yang aktual. Di negara-negara berkembang seperti Indonesia telah merasakan tantangan berat dalam menjalankan satu sistem pemerintahan. Tantangan itu salah satunya datang dari pola multikulturalisme. Robert Kaplan mengemukakan, dalam menemukan fakta bahwa demokrasi tidak menyelamatkan bangsa Afrika adalah masihnya konflik antar suku, agama ras dan budaya.

Demokrasi hanya mengandalkan partai politik yang berfungsi sebagai agregasi kepentingan (Interest Aggregation) yang berbasis agama dan kesukuan. Ketika dilaksanakan pemilu yang terjadi justru pertempuran yang berlumuran darah dan bukan arena perebutan kekuasaan yang rasional. Fenomena ini agak berbeda di Indonesia, justu konflik suku dan agama menjadi satu satu kejadian yang berkepanjangan mengingat pola multikulturalisme itu rentang akan konflik horizontal.

Sejak tahun 1994 Freedom House (FH) telah mencatat tentang suramnya prospek demokrasi ketika dalam laporannya ditemukan sebagain besar ke - 50 negara "tidak bebas", yakni 49 negara-negara itu memiliki satu satu lebih dari 3 karakteristik berikut: 1) mereka mengalami populasi mayoritas Muslim dan sering mendapat tekanan-tekanan fundamentalis Islam yang kuat; 2) Mereka mengalami kerasnya perpecahan etnis tanpa sebuah kelompok etnis yang dominan; 3) Mereka memiliki rezim neo-komunis atau pasca komunisme dengan dominasi satu partai politik yang menyebar kuat. Bahkan pada laporan tahun 2002, FH malah menemukan bahwa dunia Islam secara umum gagal membangun rezim.

Jika begitu, apakah Indonesia sebagai Negara yang menganut sistem demokrasi merasakan hal tersebut? Bisa iya bisa juga tidak. Jika tantangan demokrasi di Indonesia masing-masing memiliki maksud dan tujuan untuk saling mendominasi tentu catatan FH diatas nyata terjadi. Jika ditarik ke Indonesia, penulis sepakat dari 3 temuan $\mathrm{FH}$ diatas secara struktural memang sudah tidak ada tapi tak menampik hal tesebut bergerak secara kultural (Syahrul, 2018).

Sejak Indonesia merdeka tahun 1945 silam demokrasi hadir sebagai pelengkap juga berupa kesepakatan yang betul-betul hadir untuk menciptakan keselarasan antar masyarakat. Dengan hadirnya demokrasi kebebasan tak dibatasi lagi tidak seperti yang terjadi pada masa Orde Baru. Bangsa Indonesia banyak memahami bahwa kebebasan yang ditawarkan oleh sistem ini merupakan kebebasan mutlak yang pada akhirnya menggunakan demokrasi sebagai alat untuk saling menjatuhkan.

Di negara-negara berkembang seperti Indonesia, suku dan agama tak sebagian dari mereka yang ingin berkontestasi di pemilu hanya menjadikan suku dan agama sebagai objek untuk mendulang suara. Ini pun tragis, setelah mereka mendapatkan suara di bilik suara mereka enggan lagi untuk berkunjung bahkan tak sedikit dari mereka justru menambah beban, meninggalkan masalah hingga ini diberangus. 
Fenomena tersebut memantik kita untuk melihat secara gamblang bagaimana demokrasi berjalan. Tantangan demokrasi yang paling tragis justru datang dari produk-produk demokrasi itu sendiri. Bahkan salah satu Tokoh NU, HM. Subchan ZE pernah mengatakan "Demokrasi bisa terbunuh oleh lembaga demoktis lewat prosedur yang demokratis". Disini, demokrasi akan lumpuh karena produk-produk demokrasi (Elit Politik) itu sendiri. Perilaku para elit politik menjadi anti tesis dari demokrasi yang paripurna, mereka mendaftar kerena demokrasi, kampanye atas nama demokrasi, pidato atas nama demokrasi, duduk karena demokrasi, menikmati fasiltas karena demokrasi tapi kebijakan atas kehendak dan kemavan sendiri; habis manis sepah dibuang, kebebasan yang tak mengenal aturan main dipertontonkan.

Mereka menggerayangi dan menikmati demokrasi, tak ubahnya seperti seorang perempuan merengek-rengek meminta pertanggungjawaban atas perlakukannya. Kenikmatann itu diperlihatkan, mereka menikmati rakyat yang tertindas, entah rakyat harus meminta kepada siapa pertanggungjawaban itu. Ini cabul!!! Dimana? Jangan bertanya pada rumput yang bergoyang tapi bertanyalah kepada mereka yang sedang bergoyang-goyang di kursi goyangnya.

Dari argumen diatas, dapat kita katakan bahwa salah satu pentingnya institusi dan multikultural adalah mampu mengakomodasi hak-hak minoritas dalam sebuah institusi politik, tetapi tidak hanya itu hal tersebut harus seiring sejalan dengan realitas sosial yang selalu berubah-ubah. Mengapa begitu penting mengakomodasi hak-hak minoritas dalam institusi politik. Sebab, ini persoalan kemanusiaan yang sebenarnya harus sama di mata hukum. Negara sebagai sebuah institusi yang memiliki wewenang menjalankan dan menerapkan undang-undang tanpa harus membeda-bedakan agama, suku, ras dan budaya.

Memasuki abad ke-20 hari ini, isu-isu agama, suku, ras dan budaya menjadi satu isu yang tidak boleh dipandang remeh, tidak boleh dipandang sebelah mata. Sebab, isu-isu tersebut menjadi sangat sensitif jika diperhadapkan dengan dunia politik. Kita lihat penjelasan sebelumnya bahwa bangsa Afrika dalam proses politik atau pemilihan umum mereka tidak lagi beradu gagasan secara rasional melainkan beradu etnis. Bagi siapa yang etnis kuat (super power) maka merekalah yang akan terpilih, sekalipun harus mengorbankan nyawa. Tentu di Indonesia yang kita kenal sebagai negara heterogen yang memiliki keanekaragaman (local wisdom) tidak ingin mengalami hal yang serupa. Sebab, ini menyangkut hal kemanusian. Bagi penulis, tidak ada negosiasi dalam hal kemanusiaan, jika kemudian timbul sebuah pertanyaan haruskah masyarakat multikultural mengakomodasi hak minoritas dalam sebuah institusi? Jawabannya, harus. Karena Indonesia sebagai institusi negara yang didalamnya terdapat masyarakat-masyarakat mayoritas, harus 
mengakomodasi hak-hak mereka. Karena kita semua sama dalam paying negara hukum, semua sama di mata hukum tanpa membeda-bedakan kelompok-kelompok tertentu.

Undang-undang juga telah menjamin akan hal itu, tak ada satupun manusia yang harus dibatasi haknya, baik itu hak politik, hak agama, hak suku, dan hak ras. Sebab, negara harus menjadi instrument bagi masyarakat. Kesejahteraan masyarakat dapat dilihat dari sejauhmana negara multikultural mampu mengakomodasi seluruh hak-hak minoritas tanpa adanya kepentingan. Permasalahannya kemudian adalah ketika konsensus dalam proses mengakomodasi kepentingan minoritas sudah disusupi oleh kelompok-kelompok yang hanya ingin mementingkan pribadinya, terkadang konsensus tersebut akan mengalami kemacetan yang serius. Oleh sebab itu, karena negara adalah salah satu organisasi yang bertugas untuk melindungi seluruh hak warganya maka sepatutnya ketimpangan yang terjadi di masyarakat harus dihilangkan.

Multikultural dapat dijadikan sebagai alat untuk meretas segala ketimpang yang terjadi, kita tidak ingin permasalah bangsa ini semakin masif oleh karena perbuatan para bandit-bandit politik yang saat ini duduk manis di kursi kekuasaan sedang rakyat yang mengantarkannya duduk dikursi itu justru semakin sengsara. Kita tidak ingin multikultural hanya dijadikan sebagai ilmu pengetahuan bunyi-bunyian yang hanya datang menjadi mala petaka di negara-negara demokratis seperti Indonesia. Empat pilar kebangsaan; Pancasila, Undang-undang 1945, Bhineka Tunggal Ika dan Negara Kesatuan Republik Indonesia harus dijadikan sebagai pedoman hidup berbangsa dan bernegara. Indonesia sebagi institusi harus mengakomodir seluruh kepentingan-kepentingan masyarakat tanpa terkecuali. Olehnya sebab itu, aturan harus merata dan harus diterapkan bagi seluruh warga negara Indonesia tanpa pandang bulu.

Karena peradaban bangsa dimulai dari sejauhmana masyarakatnya (mayoritas) mampu menerima yang sulit bahkan tidak bisa ia terima (minoritas), itulah kunci dari multikultural. Agama yang berbeda, suku yang berbeda, budaya yang berbeda, ras yang berbeda harus ditunjang dengan semangat peradaban nasionalisme yang sedari dulu telah diperjuangkan oleh para pendiri bangsa. Jika beban bangsa semakin berat maka hanya ada satu kata yang akan meretasnya yaitu, persatuan dan kesatuan serta menghargai sesama warga negara.

Multikulturalisme dan politik anti kekerasan di Indonesia menghadapi kondisi problematis saat ini, pengalaman negara mengelola perbedaan tidak berbading lurus dengan kondisi lapangan yang menunjukkan meningkatnya konflik horizontal. Kasus kekerasan antar etnis dan umat beragaman di Yogyakarta yang terjadi di pertengahan tahun 2014 ini telah menyentak kita bahwa multikulturalisme dan politik anti kekerasan bukanlah proyek temporer negara. Melainkan sebuah pemahaman dan cara berpikir yang perlu dikembangkan terus-menerus oleh semua pihak, sehingga multikulturalisme sebagai filosofi 
yang mengarahkan semua pihak agar mau saling mendengar dan memahami satu sama lain, tanpa harus menanggalkan prinsip dan keyakinan pribadinya. Revitalisasi dan penegakan filosofi multikulturalisme menjadi rujukan untuk melakukan penguatan peran politik rakyat di hadapan negara, membudayakan diskusi publik dalam proses pengambilan dan penentuan kebijakan, optimalisasi peran dan fungsi institusi lokal sebagai instrumen resolusi konflik dan negara harus mampu menjadi katalisator dalam pemberian peran ekonomi politik. Adapun hasil akhirnya diharapkan warga yang heterogen bisa hidup bersama-sama meskipun berbeda etnis, agama dan ras, sehingga mereka dapat saling menghormati dan memunculkan sikap toleransi ( Nugroho, 2013).

Salah satu upaya untuk mendorong ketertiban negara sehingga konflik antar etnis tak terjadi lagi adalah partai politik. Partai politik harus bertanggungjawab, mereka harus menjadi jembatan atas setiap keluhan-keluhan masyarakat terhadap pemerintah. Masifnya konsolidasi kebangsaan menjadi satu kekuatan (one power) dalam menjaga ketahanan dan keamanan bangsa. Oleh sebab itu, seiring berjalannya waktu multikultulisme ini harus diuji, saya mengutip perkataan salah satu filsuf, Karl R Popper yang mengatakan bahwa sebuah karya tidak dikatakan ilmiah ketika is tidak tahan uji. Indonesia saat ini menerima multikultural tersebut sehingga harus diuji. Jika demikian dalam proses pengujiannya justru lebih banyak menbawa dampak negatif maka kita butuh pendekatan lain yang bisa mengkritik pendekatan tersebut, ini yang saya sering sebut Neo-Multikultural.

Cita-cita reformasi yang nampaknya mengalami kemacetan dalam pelaksanaannya sebaiknya digulirkan kembali. Secara model, alat penggulir bagi proses-proses reformasi dapat dioperasionalkan dan dimonitor, yakni dengan mengaktifkan model multikulturalisme untuk meninggalkan masyarakat majemuk, dan secara bertahap memasuki masyarakat multikultural Indonesia. Sebagai model, masyarakat multikultural Indonesia adalah sebuah masyarakat berdasarkan ideologi multikulturalisme, atau bhinneka tunggal ika yang multikultural, yang melandasi corak struktur masyarakat Indonesia pada tingkat nasional dan lokal (Suparlan, 2002). Artinya, dalam tahap perubahan sosial institusi dituntut untuk update dalam setiap perkembangan zaman serta perkembangan masyarakat. Sebab, sebagai negara multikultural yang didiami oleh budaya yang berbeda-beda, mereka pun juga membutuhkan pedoman dalam berbangsa dan bernegara yang yakini mampu memberikan satu frame berpikir agar konflik horizontal semakin berkurang bahkan tidak ada lagi. Momentum politik diharap menawarkan isu-isu yang produktif sehingga konflik etnis pun juga hilang. 


\section{KESIMPULAN}

Negara Indonesia sebagai negara multikultural diharap mampu memberikan pelajaran bagi seluruh dunia tentang arti keberagaman serta menjalankan kehidupan sehari-hari dalam masyarakat multikultural. Institusi menjadi jembatan dalam menyerap segala aspirasi masyarakat dan menjalankan hukum serta menerapkan hukum tanpa pandang bulu. Mengakomodasi seluruh hak-hak minoritas dalam institusi politik. Sebab, itu harus dilakukan oleh masyarakat multikultural demi menjaga keberlangsungan orang banyak. Konflik multikultural yang tak pernah hilang menjadi satu tugas besar kita dalam menawarkan solusisolusi yang produktif. Tantangan masyarakat Indonesia yang kaitannya dengan multikultural sebenarnya bukan pada harus atau tidaknya masyarakat multikultural mengakomodasi hakhak minoritas dalam institusi politik tetapi konflik-konflik yang sumbernya dari akar rumput. Ditambah dengan sumber konflik yang datangnya dari para elit politik dan para politisi yang sering membawa-bawa isu-isu etnis/multikultural ke dalam momentum politik yang sering kita dengar dengan sebutan pesta demokrasi. Konflik suku, agama ras dan budaya yang tak pernah hilang di pelupuk mata. Hukum telah menjamin bahwa semuanya sama di mata hukum, termasuk hak berpolitik. Hukum tak boleh dipermainkan terutama dalam hal politik. Sebab, Indonesia negara hukum, hukum harus ditegakkan bagi seluruh masyarakat Indonesia. Jika begitu, keberlangsungan kehidupan berbangsa dan bernegara, saling menghormati maka akan semakin harmoni kehidupan ini. Oleh sebab itu, kekuatan dari multikulturalisme dalam institusi adalah bagaimana pendekatan ini bekerja dalam menjaga keharmonisan bangsa dan negara. 


\section{DAFTAR PUSTAKA}

Bissondath, N. (2002). Selling Illusions: The Myth of Multiculturalism. Toronto: Pinguin.

Bond, R. (2006). Belonging and Becoming: National Identity and Exclusion. Sociology, 4(40).

Danang Risdiarto. (n.d.). Minority Group Protection in Indonesia to Realize Juctice and Equality Before the Law. Jurnal Rechtsvinding, 6(1).

David Easton. (1968). "Political Sciense", Internasional Encyclopedia of the Social Science. New York: The Macmillan Company and the Free Press.

Fathullah Syahrul. (2018). Mencabuli Demokrasi. Available from: http://suakaonline.com/13692/2018/12/21/mencabuli-demokrasi/[Accessed Februari 7, 2020].

Heru Nugroho. (2013). Multikulturalisme dan Politik Anti Kekerasan. Jurnal Pemikiran Sosiologi, 2(2).

Nur A. Fadhil Lubis. (2019). Multikulturalisme dalam Politik: Sebuah Pengantar Diskusi. Jurnal Antropologi Sosial Budaya ETNOVISI, 2(1).

M.C. Ricklefs. (1991). A History of Modern Indonesia. Jakarta: PT. SERAMBI ILMU SEMESTA.

Miriam Budiardjo. (2008). Dasar-Dasar Ilmu Politik. Jakarta: PT Gramedia Pustaka Utama.

Muslim Mufti. (2012). Teori-Teori Politik. Bandung: CV Pustaka Setia.

Parekh, B. (2001). Rethinking Multiculturalism. Harvard: Harvard University Press.

Parsudi Suparlan. (2002). Menuju Masyarakat Indonesia yang Multikultural. Jurnal Antropologi Indonesia, Volume 69.

Poster, M. (1992). Postmodernity and the Politics of Multiculturalism: The Lyotard-Habermas Debate Over Socia I Theory. Modern Fiction Studies.

Suprapto. (2012). Membina Relasi Damai Antara Mayoritas dan Minoritas (Telaah Kritis atas Peran Negara dan Umat Islam dalam Mengembangkan Demokrasi di Indonesia. Jurnal Analisis, 11 (1). 